\title{
Comparative Study of Physicians' Job Satisfaction Levels in the Public and the Private Sectors in Russia
}

\author{
Maria Shkolnikova1, Michael Yugay², Victoria Pankevich ${ }^{2 *}$ \\ ${ }^{1}$ Research Clinical Institute for Pediatrics of the Pirogov Russian National Research Medical University, Moscow, Russia \\ ${ }^{2}$ National Research University Higher School of Economics, Moscow, Russia \\ Email: m_shkolnikova@pedklin.ru,myugay@hse.ru, ^vika-pankevich@mail.ru
}

How to cite this paper: Shkolnikova, M., Yugay, M. and Pankevich, V. (2017) Comparative Study of Physicians' Job Satisfaction Levels in the Public and the Private Sectors in Russia. Open Journal of Social Sciences, 5, 101-113.

https://doi.org/10.4236/jss.2017.58008

Received: July 9, 2017

Accepted: August 5, 2017

Published: August 8, 2017

Copyright $\odot 2017$ by authors and Scientific Research Publishing Inc. This work is licensed under the Creative Commons Attribution International License (CC BY 4.0).

http://creativecommons.org/licenses/by/4.0/

\begin{abstract}
Job satisfaction is widely seen as a significant factor in an organisation's efficiency. In healthcare, job satisfaction is very important because it helps to develop a clinic's human resource potential, and thus to influence the quality of the medical services provided. The aim of this study is to compare physicians' job satisfaction levels in public, private, and departmental healthcare organisations. Respondents were asked to evaluate their overall attitude towards their work and their levels of satisfaction with factors such as salary, working conditions, and team atmosphere. The results of the study showed that the physicians with the highest job satisfaction levels are in the private sector (67\%), whereas physicians in the departmental and the public sectors have much lower job satisfaction levels ( $9 \%$ and $11 \%$, respectively). In terms of salary, physicians who work in public clinics have lower levels of satisfaction (11\%) than physicians who work in other types of clinics. Most of the physicians surveyed appear to be content with the team atmosphere in their workplace, with around $70 \%$ of respondents in all organisation types indicating that they are satisfied with this aspect of their work. Logistic regression analysis showed that the motivating factor which most influences the satisfaction levels of healthcare workers in public clinics is their working conditions, whereas the factor that most influences the satisfaction levels of physicians in the private sector is their salary. Meanwhile, the factors that most influence the satisfaction levels of physicians in departmental organisations are both their working conditions and their salary.
\end{abstract}

\section{Keywords}

Job Satisfaction, Hospitals, Physicians, Incentives, Motivation 


\section{Introduction}

The success of every healthcare organisation depends on various factors. The main reasons for studying these factors are to increase the efficiency of an organisation and to ensure that the organisation's employees reach their full potential. One of these factors is physicians' and nurses' job satisfaction (JS). While the importance of this factor is generally recognised, additional investigations of satisfaction levels are necessary as external conditions and societal values are constantly changing. The available data indicate that workers who are content with their job are more hardworking, efficient, disciplined, and better at managing their time than workers who are not satisfied [1]-[6]. Therefore, if the employees in an organisation report high levels of job satisfaction, it may be expected that the organisation would have high levels of efficiency [7]-[12]. Survey results in various countries show that healthcare workers' JS levels depend on many factors. For example, physicians working in a hospital in Orlando (Florida, USA) rated their relationships with patients and colleagues and their opportunities for self-development as the most significant contributors to their JS [9]. A survey conducted in a public clinic in Serbia showed that JS grows with physicians' levels of education [12]. It was also revealed that the majority of respondents $(76 \%)$ feel overloaded with work and do not have an opportunity to influence their job. Several studies of physicians' JS have also been conducted in Russia. For example, a survey conducted in two regional public hospitals in Saint Petersburg and Astrakhanskaya oblast found that more than two-thirds of physicians $(67.7 \%)$ are not content with their job [13]. The results further showed that a similar share of respondents believed their reimbursement is insufficient, and almost $80 \%$ feel overloaded at work. The most motivating factor cited by the physicians surveyed was the opportunity to help other people.

What does the term "worker's job satisfaction" mean? There is currently no single definition of this term. Initially, JS was described in the literature on basic motivation theories. For example, according to a theory proposed by Herzberg [14], JS is determined by motivating and hygienic factors. A different theory outlined by Hackman and Oldham [15] suggests that workers are content with their job when five core job characteristics (skill variety, task identity, task significance, autonomy, feedback) are present. According to the Adams' Equity Theory [16], the perception of fairness at work strongly influences a worker's JS, and thus the correlation of inputs and outputs should be the same across the workers in a given organisation. One of the first researchers of JS as a particular phenomenon, Edwin Locke [17], argued that JS represents the difference between a worker's expectations concerning his or her job and the worker's actual situation. Other researchers, including Paul Spector [18], have posited that JS can be described in a general way (whether the worker likes or dislikes his or her job) or through the evaluation of various work facets. In the analysis of different theories regarding JS, one particular definition of JS stands out, and is used for this study: JS is based on the level of contentment that the worker has with the 
requirements and expectations associated with his or her job, which in turn informs the employee's overall attitude towards his or her work.

The study of workers' JS is particularly important today because human resources have become the main factor that determines an organisation's efficiency. There is substantial evidence that it is rather difficult to run a company in which the employees have low levels of JS. When studying physicians' job satisfaction, particular attention should be paid to the conditions and the features of their work, including whether the physicians are employed by a public, a private, or a departmental organisation. The main objective in the public sector is to utilise public finances in the most efficient way possibly, whereas the main objective in the private sector is maximum profitability. Thus, we can assume that a private sector organisation has greater incentives than a public sector organisation to develop and implement various instruments to increase its efficiency. However, a public sector organisation may be more entrenched with the traditions and associations of particular specialists, and it could adopt some practices from the private sector, especially in the area of workers' motivation.

Therefore, the purpose of the study was to examine the features of Russian physicians' job satisfaction depending on the type of the sector where they work and to carry out a comparative analysis.

Practical social significance of the research lies in the fact that the study was aimed at the development of the recommendations for the heads of medical organizations on how to make workers more content with job. What is more, the analysis of the studies related to the topic showed that previously no articles described the difference between job satisfaction in public and private healthcare organizations in Russia. The results of the current research are based on the statistical analysis of primary data and cover important gaps in scientific field, what proves its academic significance.

\section{Methods}

The aim of the research was to compare the levels of job satisfaction of physicians working in public, private, and departmental ${ }^{1}$ medical organisations in Moscow. The data were collected in 2014-2015 in three types of healthcare organisations in Moscow: public, private, and departmental. The research sample consisted of 469 physicians. The data were collected with a specially designed questionnaire. The idea was to create a questioner which would cover the major constituents of the job satisfaction and evaluate the aspects of work which could influence it. At the same time, we did not want our respondents to spend too much time answering the questions that is why the questioner consisted of nine closed-ended questions:

- How long have you been working in this medical organisation?

${ }^{1}$ In Russia departmental medical organizations are established by government institutions or public corporations in order to provide medical care to their workers. The aim of such organizations is to serve a certain target group of people. These organizations can also provide medical services to other people for additional fees. 
- To what extent are you satisfied with your job?

- To what extent are you satisfied with the level of your salary?

- To what extent are you satisfied with your working conditions?

- To what extent are you satisfied with the team atmosphere in your workplace?

- What would you like to improve in your working conditions?

- Do you educate yourself?

- Which sources of information do you use for self-education?

- What incentives do you consider to be the most important for you?

Questionnaires were submitted to 65 clinic administrative offices and then distributed among physicians ${ }^{2}$. The study sample consisted of 229 physicians working in public hospitalssituated in 10 (out of 12) different Moscow districts (48.8\% of the sample), 195 physicians working in 2 large departmental hospitals (41.5\% of the sample), and 45 physicians working in one of the Top 5 private clinics in Moscow (9.6\% of the sample). Therefore, the sample can be considered as representative because it reflects in relevant to the general structure of the medical organizations in Moscow proportions the physicians of different types of the clinics. All of the answers were converted into figures and processed with SPSS statistics 22.0.

The data analysis included crosstabs, descriptive statistics, and logistic regression analysis. Logistic regression analysis was usedto evaluate how the physicians' levels of satisfaction with their salary, their working conditions, and the team atmosphere in their workplace influenced the likelihood that they would report being satisfied or dissatisfied with their job. This type of analysis was chosen because it allowed us to pay particular attention to the differences between two groups of respondents: those who are satisfied and those who are dissatisfied. The dependent variable (job satisfaction) was thereforebinary. The logistic regression model was:

$$
\operatorname{Pr}=g\left(p_{0}+p_{1} x_{1}+p_{2} x_{2}+p_{3} x_{3}\right),
$$

where $g(z)$ is logic-function $g(z)=1 /\left(1+\mathrm{e}^{-\mathrm{Z}}\right), p_{0}$-constant, $X_{1}, X_{2}, X_{3}$-resulting explanatory variables "satisfaction with salary", "satisfaction with working conditions", "satisfaction with team atmosphere" respectively, $p_{1}, p_{2}, p_{3}$-regression coefficients and $(P r)$-physicians' overall job satisfaction levels.

\section{Results}

The average level of JS reported by physicians in all types of medical organisations was less than $70 \%$. The lowest indicator was found in public medical organisations (56.3\%), and the indicator was only slightly higher in departmental organisations $(58.2 \%)$. The highest indicator was found in private organisations $(67.4 \% ; \mathrm{p}<0.05)$.

${ }^{2}$ The survey was conducted only among the clinics that expressed their ineptest to the research and gave their approval only under the condition of not disclosing their name and anonymous survey. That is why the names of the clinics are not mentioned in the article. 
The findings further revealed that the longer physicians had worked in a particular organisation, the more likely they were to report being satisfied with their job (Figure 1). Around half of the workers in the group with the highest job seniority reported being satisfied with their job. By contrast, only $6.3 \%$ of the physicians who had worked at the organisation for less than a year reported being satisfied with their work.

The analysis of physicians' levels of satisfaction with their salary showed that $71.1 \%$ of respondents in the private sector, but only $22.1 \%$ of respondents in the departmental sector and just $10.7 \%$ of respondents the private sector, reported being satisfied with their salary (Figure 2). The results further showed that $46.1 \%$ of the physicians at public hospitals reported being more satisfied than not-a figure that is $4 \%$ lower than the share found among physicians at departmental organisations. If we summarise these two groups of answers (satisfied and more satisfied than not), we see that positive answers to the question

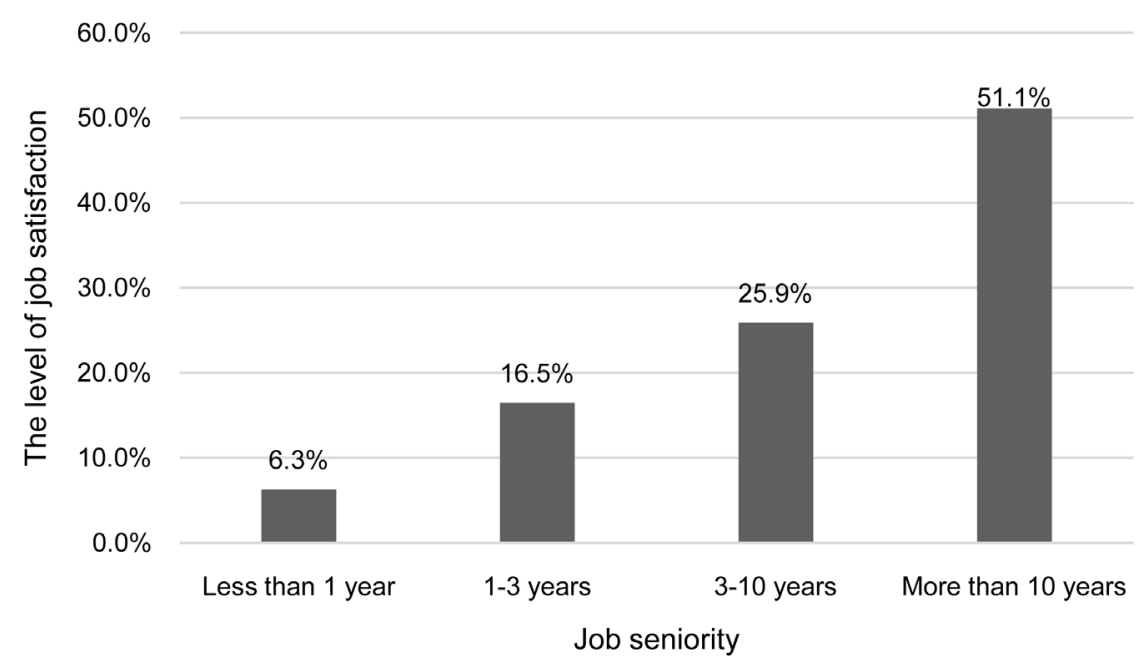

Figure 1. Physicians' job satisfaction levels and their job seniority.

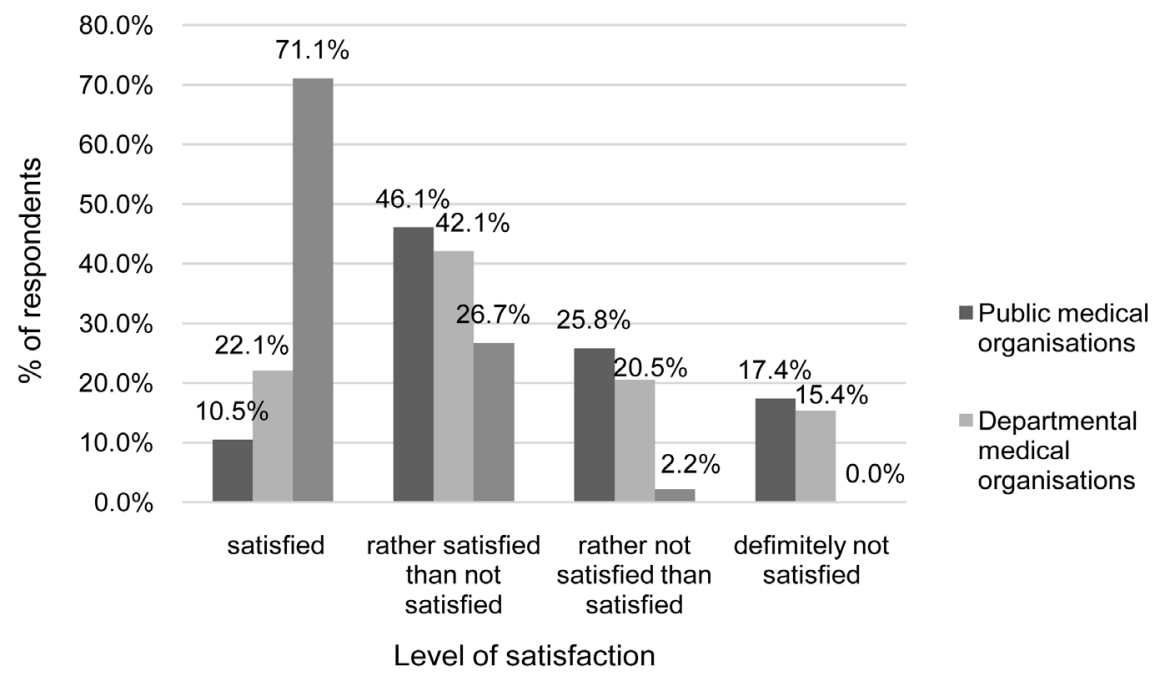

Figure 2. Physicians' satisfaction levels with salary in different types of medical organisations. 
were given by $97.8 \%$ of physicians at private hospitals, $64.2 \%$ of physicians at departmental hospitals, and $56.8 \%$ of physicians at public healthcare organisations (Figure 2). The highest share of physicians who said they are not satisfied with their salary $(43.2 \%)$ were in the public sector.

Physicians in different types of medical organisations differ in their levels of satisfaction with their working conditions. This indicator was almost the same among physicians in the public and the departmental sectors (37.6\% - 37.4\%), but was twice as high among physicians in the private sector (84.4\%) (Figure 3). The aggregated indicator of physicians' job satisfaction was $83.9 \%$ in public medical organisations, and was a full $100 \%$ in private clinics.

Levels of satisfaction with team atmosphere were rather high among physicians at all types of medical organisations, at around 70\% (Figure 4). Less than $6 \%$ of respondents reported they are not satisfied with this factor.

Nearly three-quarters (74\%, Table 1$)$ of the physicians working in public

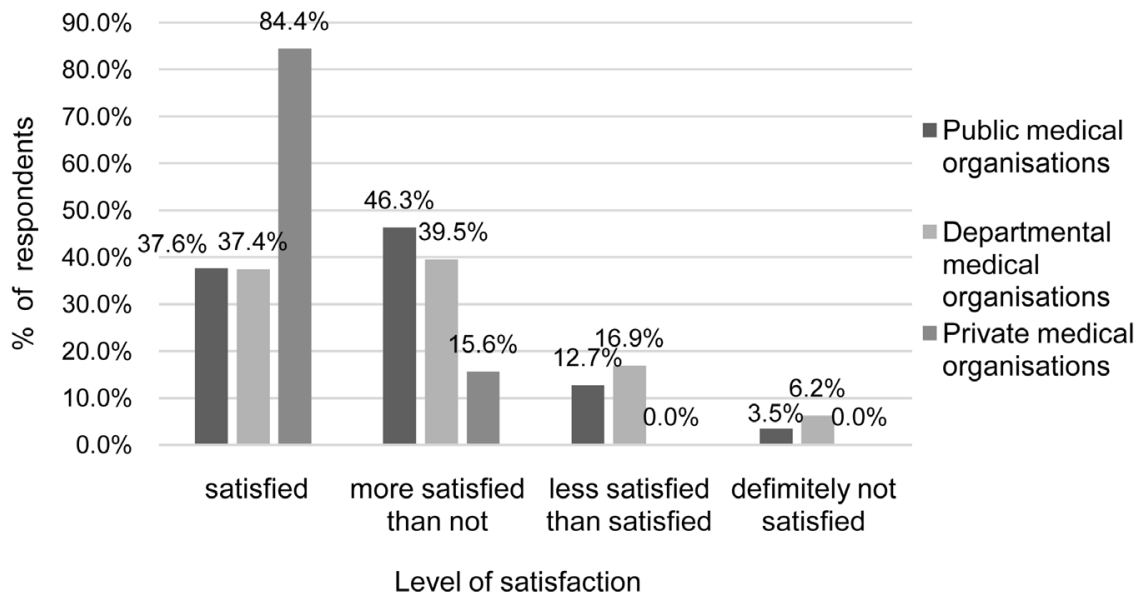

Figure 3. Physicians' satisfaction levels with working conditions in different types of medical organisations.

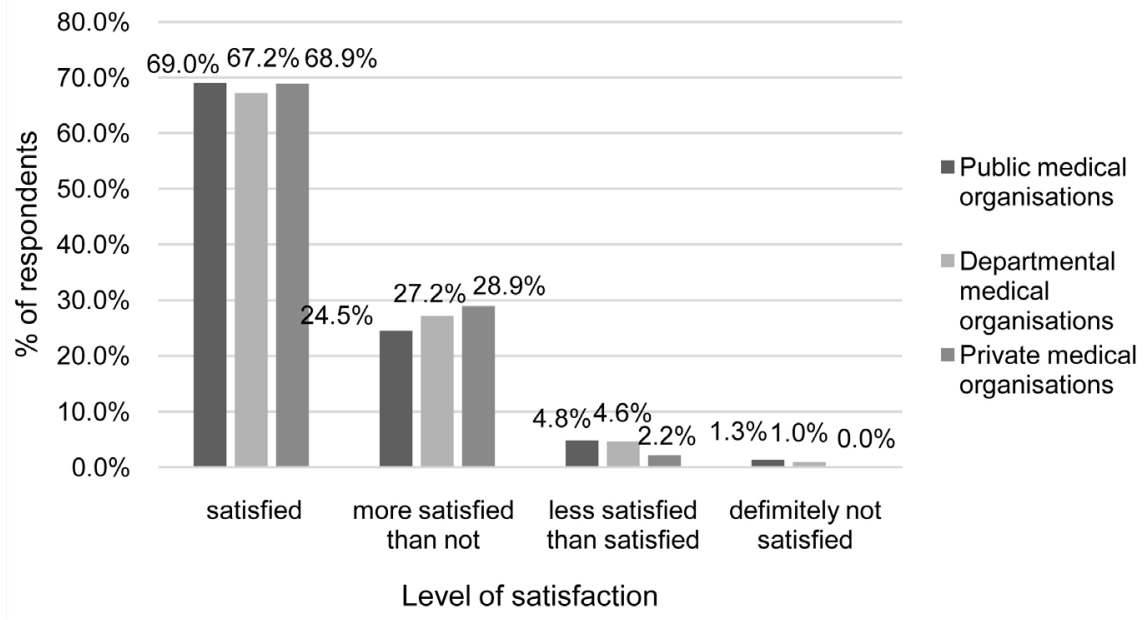

Figure 4. Physicians' satisfaction levels with team atmosphere in different types of medical organisations. 
Table 1. Aspects of their working conditions physicians would like to see improved.

\begin{tabular}{cccc}
\hline & \multicolumn{3}{c}{ Types of medical organisations } \\
\cline { 2 - 4 } $\begin{array}{c}\text { Aspects of their working } \\
\text { conditions physicians } \\
\begin{array}{c}\text { would like to see } \\
\text { improved (\% of } \\
\text { respondents) }\end{array}\end{array}$ & $\begin{array}{c}\text { Public medical } \\
\text { organisations } \\
\text { (\% of respondents in } \\
\text { public healthcare } \\
\text { organisations) }\end{array}$ & $\begin{array}{c}\text { Departmental } \\
\text { medical } \\
\text { organisations } \\
\text { (\% of respondents } \\
\text { in departmental } \\
\text { healthcare } \\
\text { organisations) }\end{array}$ & $\begin{array}{c}\text { Private medical } \\
\text { organisations (\% of } \\
\text { respondents in } \\
\text { private healthcare } \\
\text { organisations) }\end{array}$ \\
\hline $\begin{array}{c}\text { Better equipment } \\
\text { Internet access }\end{array}$ & $74 \%$ & $56 \%$ & $18 \%$ \\
Reduction in workload & $26 \%$ & $33 \%$ & $0 \%$ \\
\hline
\end{tabular}

healthcare organisationssaid they would like to see improvements in their hospital's equipment, compared to $56 \%$ of physicians in the departmental sector and just $18 \%$ of physicians in the private sector. In addition, none of the physicians in the private sector, $26 \%$ of respondents in the public sector, and $33 \%$ of respondents in the departmental sector reported that there is a need to improve internet access in their workplace. Whereas $41 \%$ of physicians at departmental clinics said they would like a decrease in their workload, surprisingly small shares of physicians at the two other types of organisations reported wanting less work.

An analysis of the survey data revealed that a salary increase is the incentive that is most valued by physicians, cited by $89 \%$ in the public sector, $93 \%$ in the departmental sector, and $84 \%$ in the private sector (Table 2). In addition, an improvement in working conditions was cited as an important incentive by around half of physicians at both public and departmental medical organisations. Community recognition seems to be appreciated more by physicians in the departmental and the private sectors than in the public sector. Less than 15\% of all respondents said they would like to be promoted and to a role with higher status.

A logistic regression analysis was conducted for each type of healthcare organisation in order to determine which factors were most influential in the public, the private, and the departmental sectors. Table 3 displays the coefficients for the independent variables and the types of healthcare organisations.

\subsection{Public Medical Organisations}

According to the results of the logistic regression, the correlations of the model are statistically significant $\left(\mathrm{p}<0.05, \chi^{2}(4)=11.724\right)$. The explained variation in the dependent variable based on our model is $16.6 \%$ (Nagelkerke $\mathrm{R}^{2}$ ). The results also show that for public healthcare organisations only one variable is statistically significant for physicians at public healthcare organisations: "satisfaction with working conditions" ( $p<0.05$ ). Thus, if a physician's level of satisfaction with his or her working conditions increases by one unit, the odds ratio that he 
Table 2. The importance of different incentives to physicians.

\begin{tabular}{|c|c|c|c|}
\hline \multirow[b]{2}{*}{$\begin{array}{c}\text { Incentive (\% of } \\
\text { respondents) }\end{array}$} & \multicolumn{3}{|c|}{ Types of medical organisations } \\
\hline & $\begin{array}{c}\text { Public medical } \\
\text { organisations }\end{array}$ & $\begin{array}{l}\text { Departmental } \\
\text { medical } \\
\text { organisations }\end{array}$ & $\begin{array}{c}\text { Private medical } \\
\text { organisations }\end{array}$ \\
\hline Salary increase & $89 \%$ & $93 \%$ & $84 \%$ \\
\hline $\begin{array}{l}\text { Improvement in working } \\
\text { conditions }\end{array}$ & $53 \%$ & $56 \%$ & $20 \%$ \\
\hline Community recognition & $21 \%$ & $43 \%$ & $40 \%$ \\
\hline Empowerment & $9 \%$ & $7 \%$ & $13 \%$ \\
\hline Promotion & $7 \%$ & $9 \%$ & $13 \%$ \\
\hline
\end{tabular}

Table 3. Logistic regressing predicting the likelihood that physicians would report being satisfied based on their salary, working conditions, and team atmosphere.

\begin{tabular}{cccccccc}
\hline & \multicolumn{2}{c}{$\begin{array}{c}\text { Public medical } \\
\text { organisations }\end{array}$} & \multicolumn{2}{c}{$\begin{array}{c}\text { Departmental } \\
\text { medical } \\
\text { organisations }\end{array}$} & \multicolumn{2}{c}{$\begin{array}{c}\text { Private medical } \\
\text { organisations }\end{array}$} \\
\cline { 2 - 7 } & Sig. & $\operatorname{Exp}(\mathrm{B})$ & Sig. & $\operatorname{Exp}(\mathrm{B})$ & Sig. & Exp(B) \\
\hline $\begin{array}{c}\text { Constant } \\
\text { Satisfaction with } \\
\text { salary }\end{array}$ & 0.327 & 5.337 & 0.282 & 0.219 & 0.038 & 0.032 \\
$\begin{array}{c}\text { Satisfaction with } \\
\text { working conditions }\end{array}$ & 0.006 & 7.110 & 0.004 & 8.080 & - & - \\
$\begin{array}{c}\text { Satisfaction with } \\
\text { team atmosphere }\end{array}$ & 0.981 & 0.972 & 0.182 & 0.007 & 18.030 & 0.010 & 10.642 \\
\hline
\end{tabular}

or she will be satisfied with his or her job increases by seven. Moreover, the correlation coefficients between variables such as "satisfaction with salary" and "satisfaction with team atmosphere" with the overall level of JS are also statistically significant (Table 4 ). Thus, these variables positively influence job satisfaction.

\subsection{Departmental Medical Organisations}

The set of variables of the model for departmental medical organisations shows significant correlation $\left(\mathrm{p}<0.0005, \chi^{2}(4)=40.173\right)$. The model explains $44.5 \%$ of the dependent variable variation. In this model, two variables are statistically significant: "satisfaction with salary" $(\mathrm{p}<0.01)$ and "satisfaction with work conditions" ( $p<0.005)$. Moreover, workers' levels of satisfaction with their salary influence the overall level of JS more significantly $(\operatorname{Exp}(B))=18.030$, Table 3 . The variable «satisfaction with team atmosphere» shows a positive significant correlation with JS ( $\mathrm{p}<0.005)$ (Table 4).

\subsection{Private Medical Organisations}

The set of variables of the model for private medical organisations shows sig- 
Table 4. Correlation coefficients with the variable "job satisfaction".

\begin{tabular}{ccccc}
\hline & & $\begin{array}{c}\text { Public medical } \\
\text { organisations }\end{array}$ & $\begin{array}{c}\text { Departmental } \\
\text { medical } \\
\text { organisations }\end{array}$ & $\begin{array}{c}\text { Private medical } \\
\text { organisations }\end{array}$ \\
\hline $\begin{array}{c}\text { Pearson } \\
\text { correlation }\end{array}$ & $\begin{array}{c}\text { Satisfaction with } \\
\text { salary } \\
\text { work conditions }\end{array}$ & 0.186 & 0.347 & 0.587 \\
& $\begin{array}{c}\text { Satisfaction with } \\
\text { team atmosphere }\end{array}$ & 0.106 & 0.375 & 0.607 \\
& $\begin{array}{l}\text { Satisfaction with } \\
\text { salary }\end{array}$ & 0.002 & 0.347 & 0.456 \\
Sig. & $\begin{array}{l}\text { Satisfaction with } \\
\text { work conditions }\end{array}$ & 0.000 & 0.000 & 0.000 \\
& $\begin{array}{l}\text { Satisfaction with } \\
\text { team atmosphere }\end{array}$ & 0.043 & 0.000 & 0.000 \\
\hline
\end{tabular}

nificant correlation $\left(\mathrm{p}<0.0005, \chi^{2}(4)=22.863\right)$, and the explained variation in the dependent variable based on the model is $55.3 \%$ (Nagelkerke $\mathrm{R}^{2}$ ). For physicians at this type of organisation only one variable appears to be statistically significant: "satisfaction with salary" $(\mathrm{p}<0.05)$. This variable also has a strong impact on the dependent variable $(J S)((\operatorname{Exp}(B))=10.642$, Table 4). Moreover, multicollinearity exists between the independent variables "satisfaction with work conditions" and "satisfaction with team atmosphere". Thus, the first variable was excluded from the model.

\section{Discussion}

The results of the research showed that physicians working in public healthcare organisations are less satisfied with their job than physicians in private and departmental clinics (56\%, 67\%, and 58\%, respectively). These differences are not as significant as we had expected. We had anticipated that this indicator would have been somewhat higher among physicians in public healthcare organisations. As a result of reforms of Moscow's healthcare system that are currently being implemented, some medical centres are being closed. Thus, it is possible that physicians at these clinics did not report being dissatisfied with their job because they were afraid of being fired. However, given the longitudinal but cross-sectional character of our research, we could not prove that this was the case. For purposes of comparison, a survey in Jordan showed that JS levels are higher among physicians working in private healthcare organisations than among physicians working in public clinics [19].

Our study also found that physicians who have been working at an organisation for a longer period of time are more content with their job. We speculate that workers with greater experience are more capable than their less experienced colleagues of evaluating their situation at work, of dealing with compli- 
cated situations at work, and of keeping their expectations low.

In addition, we found that physicians' levels of satisfaction with the team atmosphere in their workplace are rather high, and do not vary based on the type of healthcare organisation. The miniscule proportion $(0 \%-1 \%)$ of physicians who said they are not satisfied with this aspect confirms our assumption that team atmosphere is essential to medical practise, in which collaboration and mutual assistance are key elements. A similar survey conducted in Moscow in 2010 showed that the majority $(82 \%)$ of physicians are satisfied with their relationships with their colleagues [20].

The factor the physicians surveyed indicated they would most like to improve is the equipment in the public sector (Table 2). This finding is hardly surprising, as most public healthcare organisations in Moscow are in need of substantial repairs and better equipment. When asked about incentives, around $90 \%$ of physicians rated a salary increase as important (Table 3). But only $10 \%$ said they highly value a career promotion.

The logistic regression analysis showed that in the public sector working conditions is the factor that has the greatest influence on physicians' overall levels of job satisfaction. In this research, "working conditions" refers to both the physical conditions of the workplace and the way the work is organised. The fact that in Russia physicians at public healthcare organisations usually work fewer hours than physicians at private and departmental clinics could explain these results. In the private sector, salary has the strongest influence on physicians' levels of JS. Physicians in this sector usually have a salary that is several times higher than is typical in the other sectors, primarily because private clinics function in a competitive environment, and thus have to provide better conditions for both patients and workers.

In every regression logistic analysis and for every type of healthcare organisation, we found a factor that is particularly significant for workers' job satisfaction. We should, however, mention that all of the factors investigated in the research are important to some extent. This was confirmed by the statistically significant correlation coefficients we found for each of the organisation types (Table 4). This fact should be taken into consideration when developing instruments for improving healthcare workers' job satisfaction levels.

\section{Conclusions}

The results of the survey of 469 physicians working in different types of healthcare organisations in Moscow showed that physicians in private clinics have the highest average level of job satisfaction (67\%). The findings also revealed that just $14 \%$ of physicians at public hospitals, but $71 \%$ of physicians at private clinics, are satisfied with their salary. However, if we group the answers (satisfied and more satisfied than not), the gap between the physicians at these two types of organisations becomes smaller: $57 \%$ and $98 \%$ for physicians at private and public medical organisations, respectively. At departmental clinics, the share of 
doctors who reported being absolutely satisfied is twice as the corresponding share of physicians at public hospitals, and 3.5 times lower than the corresponding share of physicians at private clinics. The aggregated indicator is slightly higher than that of public healthcare organisations, or $66 \%$.

Another interesting result of the study concerns the physicians' levels of satisfaction with team atmosphere. It was revealed that levels of satisfaction with this factor are quite high (around 70\%) among physicians at all types of medical organisations. This confirms the importance of departmental support for the medical community.

Logistic regression analysis showed that the statistically significant factors which influence the probability that a physician will be content with his or her job are as follows: satisfaction with working conditions for public medical organisations, satisfaction with salary and working conditions for departmental clinics, and satisfaction with salary for private clinics. These results suggest that physicians' levels of JS-which in turn influence their efficiency-can be raised through increases in compensation and improvements in work conditions. This can be done in a number of ways, included by providing physicians with allowances, bonuses, better equipment, and other non-financial incentives. It is important to note, however, that these incentives and improvements could have different effects in different types of medical settings. In future research, it would be reasonable to study the influence of other factors on physicians' job satisfaction levels. According to a recent study of healthcare workers' motivations, financial encouragement is only seventh on the list of priorities [21]. This finding also correlates with the results of a McKinsey study that noted that non-financial incentives-such as acknowledgement from colleagues and supervisors, social contacts, and self-improvement-could be more efficient than salary increases and cash bonuses [22]. Therefore, future motivation models should be more flexible and reflect a range of workers' interests. Such motivation models would be particularly useful to medical organisations that have limited financial resources, and cannot afford to offer additional financial incentives to their workers. However, given that in contemporary society, financial capital is often substituted for social capital, and public benefits are becoming more important than individual interests; the potential for the further development of the Russian healthcare system appears to be high.

\section{Conflict of Interest}

The authors declare that they have no conflict of interest.

\section{References}

[1] Smith, P.C., Kendall, L.M. and Hulin, C.L. (1969) Measurement of Satisfaction in Work and Retirement. Rand Mc Nally, Chicago, IL, 194.

[2] Cooper, C.L., Rout, U. and Faragher, B. (1989) Mental Health, Job Satisfaction, and Job Stress among General Practitioners. BMJ, 298, 336.

https://doi.org/10.1136/bmj.298.6670.366 
[3] Rose, M. (1994) Job Satisfaction, Job Skills, and Personal Skills. Penn Retal. Skill and Occupational Change, Oxford, 244-280.

[4] Judge, T.A., Locke, E.A. and Durham, C.C. (1997) The Dispositional Causes of Job Satisfaction: A Core Evaluations Approach. Research in Organizational Behavior, 19, 151-188.

[5] Nikic, D., et al. (2008) Job Satisfaction in Health Care Workers. Acta Medica Medianae, 4, 9-12.

[6] Lysenko, I.L., Chirkov, V.A., Breusov, A.V. and Mazitov, M.R. (2014) Kachestvennye harakteristiki medicinskogo personala kak osnovnaya sostavlyayushchaya ehffektivnosti pervichnoj mediko-sanitarnoj pomoshchi. Prakticheskaya Medicina, 4, 65-68.

[7] House, R.J. and Wigdor, L.A. (1967) Herzberg's Dualfactor Theory of Job Satisfaction and Motivation: A Review of the Evidence and a Criticism. Personnel Psychology, 4, 369-390. https://doi.org/10.1111/j.1744-6570.1967.tb02440.x

[8] Bodrov, V.A. (2007) Udovletvorennost' rabotojkaksub"ektivnyjpokazatel' professional'nojprigodnosti. Chelovecheskijfaktor. Problemypsihologii i ehrgonomiki, 3 , 2-9.

[9] Medvedeva, L. (2008) Udovletvorennost' rabotnikovtrudomkakfaktorpovysheniyaehffektivnostiproizvodstva. Upravlenieehkonomicheskimisistemami: Ehlektronnyjnauchnyjzhurnal, 13, 37-45.

[10] Peters, D.H., et al. (2010) Job Satisfaction and Motivation of Health Workers in Public and Private Sectors: Cross-Sectional Analysis from Two Indian States. $\mathrm{Hu}$ man Resources for Health, 8, 27. https://doi.org/10.1186/1478-4491-8-27

[11] Jex, S.M. and Britt, T.W. (2014) Organizational Psychology: A Scientist-Practitioner Approach. John Wiley and Sons, New York, 706.

[12] Bogue, R.J., et al. (2006) Secrets of Physician Satisfaction. Physician Executive, 32, 30-39.

[13] Yur'ev, V. and Tarhanov, V. (2014) Samoocenkavrachejrazlichnyhspecial Nostejihsocial Nogostatusa i Professional Nojdeyatel Nosti. Modern Problem Science and Education, 2, 310. http://www.science-education.ru/ru/article/view?id=12498

[14] Herzberg, F., Mausner, B. and Snyderman, B.B. (2011) The Motivation to Work. Transaction Publishers, Piscataway, 157.

[15] Hackman, J.R. and Oldham, G.R. (1976) Motivation through the Design of Work: Test of a Theory. Organizational Behavior and Human Performance, 2, 250-279. https://doi.org/10.1016/0030-5073(76)90016-7

[16] Adams, J.S. (1965) Inequity in Social Exchange. Advances in Experimental Social Psychology, 2, 267-299. https://doi.org/10.1016/S0065-2601(08)60108-2

[17] Locke, E.A. (1976) The Nature and Causes of Job Satisfaction. Handbook of Industrial and Organizational Psychology, 1, 1297-1343.

[18] Spector, P.E. (1997) Job Satisfaction: Application, Assessment, Causes, and Consequences. SAGE Publications, Thousand Oaks.

[19] Bodur, S. (2002) Job Satisfaction of Health Care Staff Employed at Health Centres. Turkey Occupational Medicine, 6, 353-355. https://doi.org/10.1093/occmed/52.6.353

[20] Bussing, A. (2002) Motivaciya i Udovletvorennost. Upravleniechelovecheskimiresursami.

[21] Kuznecova, A.M. (2013) Vliyanieprioritetnyhfaktorovtrudovojmotivaciinavybor- 
professional Nojdeyatel Nostimedicinskihrabotnikov.

[22] Dewhurst, M., Guthridge, M. and Mohr, E. (2009) Motivating People: Getting beyond Money.

http://www.mckinsey.com/business-functions/organization/our-insights/motivatin g-people-getting-beyond-money

Submit or recommend next manuscript to SCIRP and we will provide best service for you:

Accepting pre-submission inquiries through Email, Facebook, LinkedIn, Twitter, etc. A wide selection of journals (inclusive of 9 subjects, more than 200 journals)

Providing 24-hour high-quality service

User-friendly online submission system

Fair and swift peer-review system

Efficient typesetting and proofreading procedure

Display of the result of downloads and visits, as well as the number of cited articles Maximum dissemination of your research work

Submit your manuscript at: http://papersubmission.scirp.org/

Or contact jss@scirp.org 